\title{
IMPACTION OF PRIMARY TEETH ASSOCIATED WITH ODONTOMA: CASE REPORTS
}

\author{
Jung-Woo Kim, Teo-Jeon Shin, Hong-Keun Hyun, Young-Jae Kim, \\ Jung-Wook Kim, Ki-Taeg Jang, Chong-Chul Kim, Sang-Hoon Lee \\ Department of Pediatric Dentistry, School of Dentistry, Seoul National University
}

\begin{abstract}
Odontomas generally appear as small, solitary, or multiple radio-opaque lesions found on routine radiographic examinations. It is a comparatively common odontogenic tumor, and may lead to interfere with the eruption of its associated tooth. In general, odontomas occur more often in permanent dentition and are very rarely associated with primary teeth.

This report deals with five rare cases of primary teeth impaction associated with odontomas, with spontaneous eruption occurring in all five cases after simple surgical removal of the odontoma. Impacted primary teeth may be associated with defects in development and eruption of their permanent successors, and thus long-term observation is necessary until the permanent successors erupt.
\end{abstract}

Key words : Odontoma, Primary teeth impaction, Spontaneous eruption

\section{Introduction}

Odontomas are benign tumors of odontogenic origin, which exhibit complete dental tissue differentiation. They consist of enamel, dentin, cementum, and pulpal tissue and comprise $22 \%$ of all odontogenic tumors ${ }^{11}$. Odontomas are considered to be developmental anomalies rather than true neoplasms ${ }^{2,3}$. The World Health Organization has subdivided odontomas into compound and complex types based on histologic and morphologic criteria $^{4}$. The calcified dental tissues in compound odontoma are arranged in an orderly pattern resembling multiple, small toothlike structures, whereas complex odontomas have an amorphous and disorderly pattern. Complex odontomas consist of a conglomerate mass of enamel and dentin, and bear no anatomic resemblance to a tooth. Compound odontomas are more frequently di- agnosed than complex odontomas, and there is a distinct difference in the location in which they proliferate ${ }^{1-4)}$. Specifically, compound odontomas are reported to occur more commonly in the incisor-canine region of the maxilla, whereas complex odontomas are more frequently located in the premolar and molar regions of the jaw bones $^{5)}$. Odontomas are usually diagnosed during the first two decades of life ${ }^{6-9}$, and in most children, these tumors are associated with tooth eruption disturbances such as delayed eruption of primary and permanent teeth or overly retained primary teeth ${ }^{6.9 .10)}$. In general, odontomas occur more often in the permanent dentition and are very rarely associated with the primary teeth $^{5,11,12)}$.

In this report, five rare cases of primary teeth impaction associated with odontoma are presented. The treatment methods and prognoses are reported in detail,

\section{교신저자 : 이 상 훈}

서울특별시 종로구 창경궁로 166 / 서울대학교 치의학대학원 소아치과학교실 / 02-2072-2680/musso@snu.ac.kr

원고접수일: 2011년 09월 01일 / 원고최종수정일: 2011년 12월 23일 / 원고채택일: 2012년 01월 05일 
and similar reports that have appeared in the literature are discussed.

\section{Case Reports}

Five cases were studied in the Department of Pediatric Dentistry, Seoul National University Hospital. There were no specific findings on the family, medical, or dental history of the patients.

\section{Case 1}

A 3-year-old boy was referred with a chief complaint of an unerupted upper right primary central incisor. Radiographic examination revealed the presence of a radio-opaque mass near the crown of the primary central incisor (Fig. 1). Surgical removal of the tiny mass was carried out under general anesthesia due to lack of patient cooperation and age. During the surgery, button bonding on the impacted incisor was carried out in case the tooth remained impacted and orthodontic traction force might be needed (Fig. 2). However, 3 months after the surgery, the orthodontic button and tip of the primary incisor were clinically observed in the intraoral environment. Full eruption of the primary incisor occurred after 5 months (Fig. 3).

\section{Case 2}

A girl aged 3 years and 2 months presented with an unerupted right maxillary primary canine. Periapical radiograph and $\mathrm{CT}$ of the upper canine region showed that multiple radio-opaque structures were present around the crown of the unerupted canine (Fig. 4). A provisional diagnosis of an odontoma was made, and the patient was scheduled for surgical removal of the lesion under general anesthesia. Signs of spontaneous eruption were seen in the radiograph, and the primary canine was positioned in the dental arch at a 6-months follow-up visit (Fig. 5).
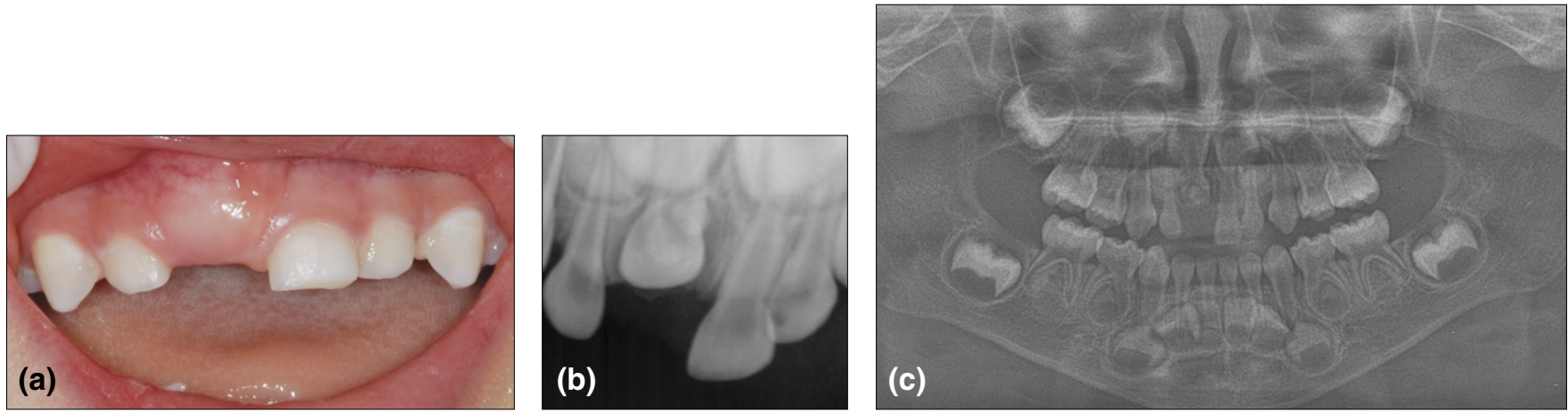

Fig. 1. (a) Clinical photograph showing delayed eruption of the upper right primary incisor. (b, c) Periapical and panoramic radiographs revealed the presence of a radio-opaque mass near the crown of the primary central incisor.
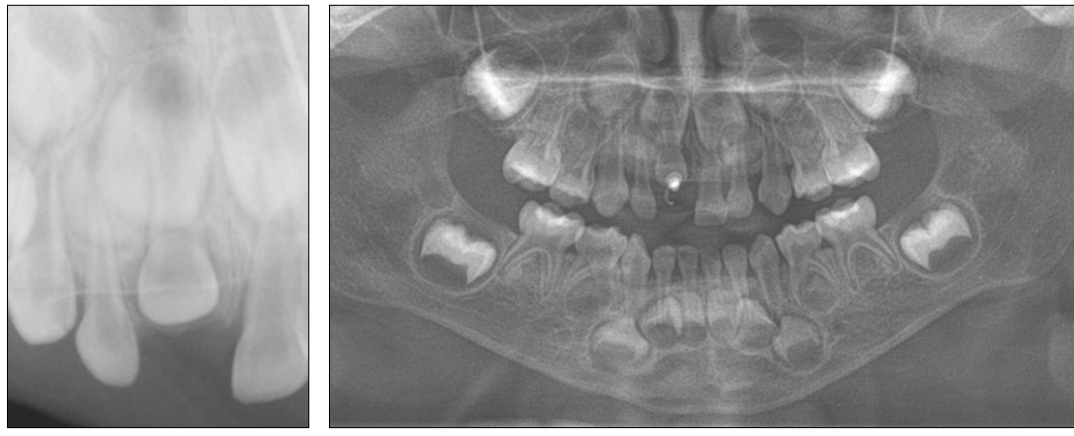

Fig. 2. Complete removal of the compound odontoma and button bonding on the primary incisor.

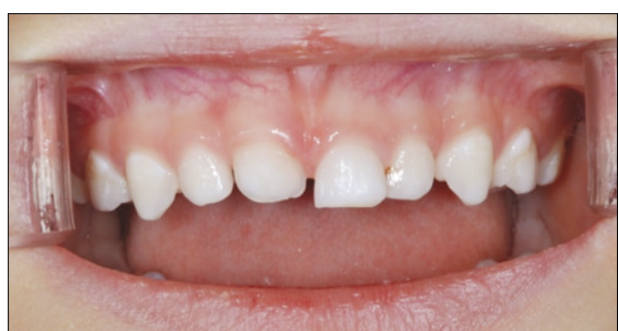

Fig. 3. The primary incisor fully erupted after 5 months. 

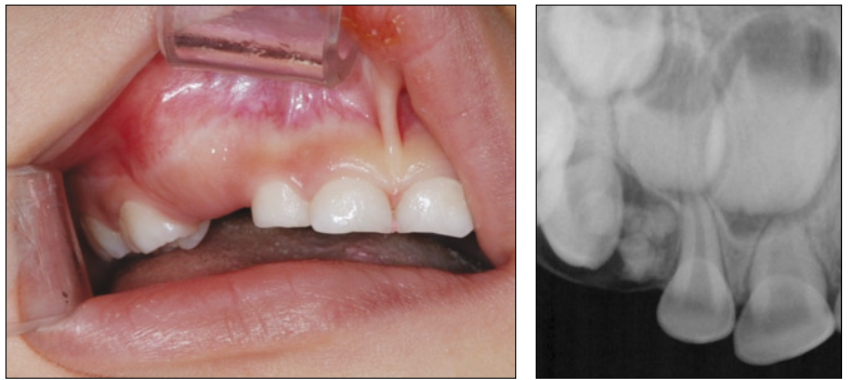

Fig. 4. Impacted upper right primary canine. Multiple radio-opaque structures are present around the crown of the primary canine.
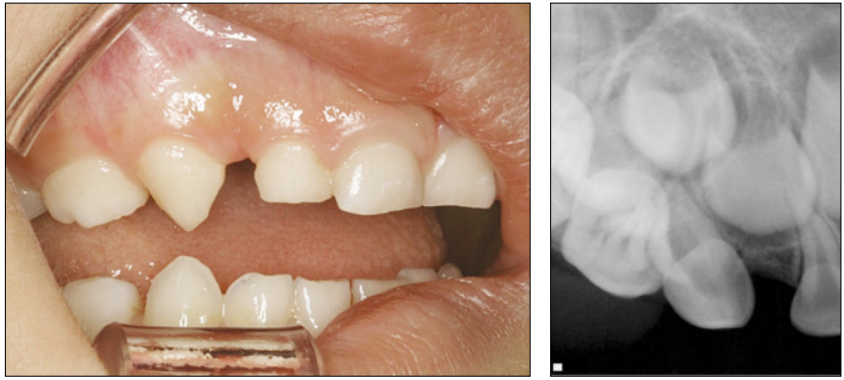

Fig. 5. Tooth movement was observed during routine follow-up, and the primary canine erupted into its position 6 months after the surgery.
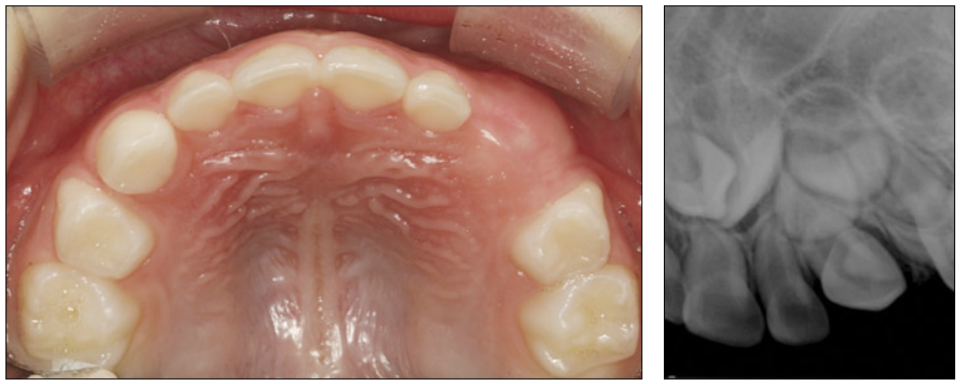

Fig. 6. Slight gingival swelling and presence of a radio-opaque structure in the upper left primary canine region.

\section{Case 3}

A boy aged 3 years and 6 months was referred for management of swelling in the left maxillary primary canine region. Periapical and panoramic radiographs were taken. Radio-opaque structures were observed overlapping the crown of the upper left primary canine (Fig. 6). A surgical procedure was carried out under local anesthesia, and histologic examination revealed a diagnosis of compound odontoma. Spontaneous eruption occurred within 3 months after the removal of the odontoma (Fig. 7).

\section{Case 4}

A five-year-old girl was referred from a local clinic due to eruption failure of the lower left primary canine. Periapical and panoramic radiographs revealed multiple radio-opaque structure just below the mesially tilted primary canine (Fig. 8). Surgical removal of the tumor was performed under conscious sedation and two small toothlike structures were extracted. The healing proce-

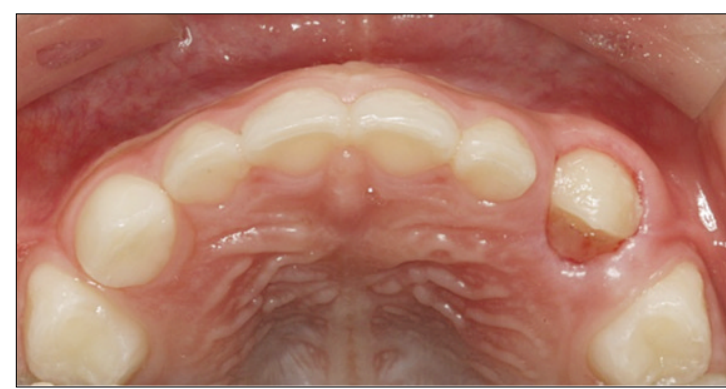

Fig. 7. Eruption of the primary canine into the intraoral environment 3 months after surgery.
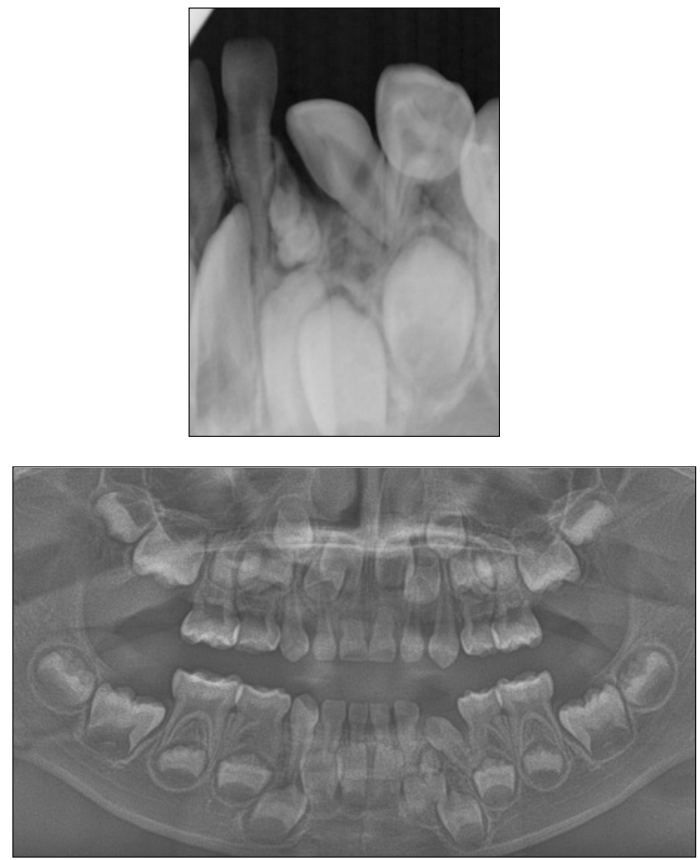

Fig. 8. Radio-opaque mass just below the mesially tilted lower left primary canine. 

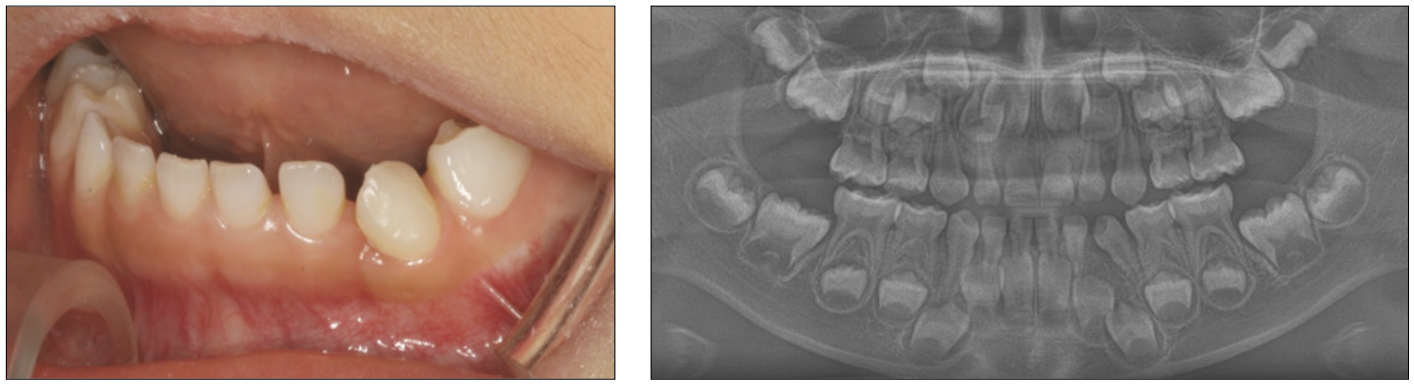

Fig. 9. Healing was uneventful and full eruption of the primary canine occurred within 3 months.

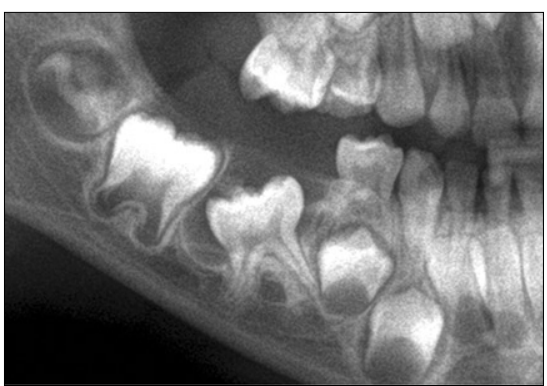

Fig. 10. Impaction of the mandibular right second primary molar caused by a tiny radioopaque mass located above the crown.

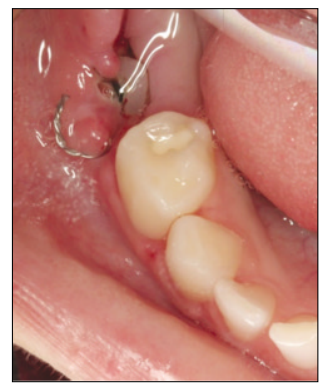

Fig 12. An orthodontic button can be seen due to the spontaneous eruption of the primary molar.
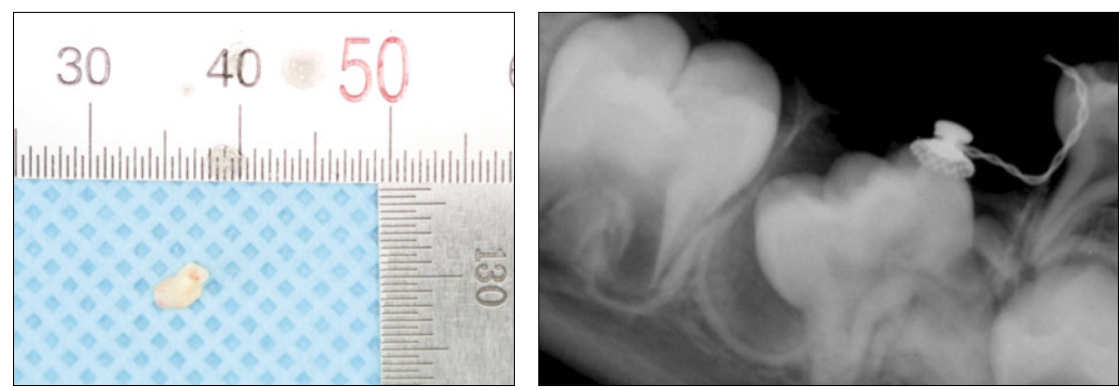

Fig. 11. Removal of the compound odontoma and button bonding were carried out under local anesthesia.

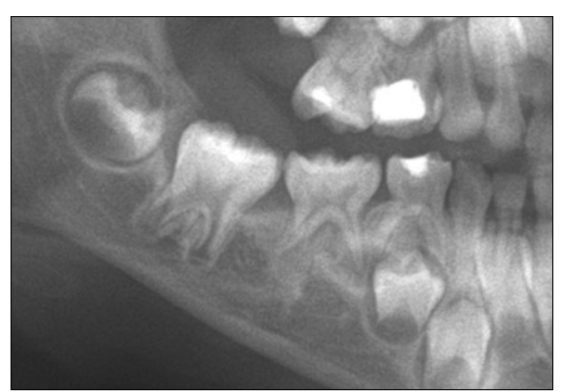

Fig. 13. The second primary molar was fully erupted at the 1-year follow-up visit. dure was uneventful and full eruption of the primary canine occurred within 3 months (Fig. 9). The gingiva was very natural and healthy looking.

\section{Case 5}

A boy aged 5 years and 2 months presented with an impacted lower right primary second molar. A tiny radioopaque mass, which caused the impaction, was observed right above the primary molar crown in periapical and panoramic radiographs (Fig. 10). The succedaneous tooth, which is the second premolar, was congenitally missing. The patient was scheduled for surgical removal of the lesion and the operation was performed under local anesthesia. The chance of re-eruption of this impacted primary molar was anticipated as being very slim, and thus button bonding was carried out during the surgery in case orthodontic traction was later needed (Fig. 11). Post-operative recovery was uneventful, and the patient was followed-up regularly to monitor the eruption of the impacted primary second molar. Although eruption occurred at a very slow rate, signs of spontaneous eruption were observed after 3 months by routine periapical radiograph (Fig. 12). At the 1-year follow-up visit, the lower right primary second molar was in its originally intended position in the dental arch (Fig. 13). 
Table 1. Summary of the five case reports

\begin{tabular}{ccccccc}
\hline Case & Gender & Age & Impaction area & Type of odontoma & Method of treatment & Full eruption period after treatment \\
\hline 1 & Male & $3 \mathrm{Y}$ & $\# 51$ & Compound & Surgical removal & 5 months \\
2 & Female & $3 \mathrm{Y} 2 \mathrm{M}$ & $\# 53$ & Compound & Surgical removal & 6 months \\
3 & Male & $3 \mathrm{Y} 6 \mathrm{M}$ & $\# 63$ & Compound & Surgical removal & 3 months \\
4 & Female & $5 \mathrm{Y} 3 \mathrm{M}$ & $\# 73$ & Compound & Surgical removal & 3 months \\
5 & Male & $5 \mathrm{Y} 2 \mathrm{M}$ & $\# 85$ & Compound & Surgical removal & 12 months \\
\hline
\end{tabular}

Summary of the five case reports are presented in Table 1.

\section{Discussion}

"Tooth impaction" is defined as a cessation of the eruption of a tooth caused by a clinically or radiographically detectable physical barrier in the eruption path or by an ectopic position of the tooth. Typical examples of barriers are supernumerary teeth, odontomas, cysts, crowded tooth germs and erupted teeth ${ }^{13.23}$. Teeth with eruption problems are mainly permanent teeth and rarely primary teeth. Moreover, most odontomas are associated with permanent teeth and rarely with primary teeth $^{5,8,11}$. Indeed, there are very few reports in the literature of odontomas associated with unerupted primary teeth $^{5.14-18.23 .24)}$. Katz found only 5 cases (1.26\%) of compound and complex odontomas in association with unerupted primary teeth in his analysis of 396 cases of odontoma. These figures reaffirm the rarity of the five cases presented in this report.

The treatment advocated for odontomas in both primary and permanent dentition is surgical removal. If odontomas are extirpated early without disturbing the underlying tooth germ, eruption of the impacted tooth is $\mathrm{ex}^{-}$ pected to occur spontaneously or after orthodontic traction $^{10,12.14,15,18,19)}$. Of the five cases presented, button bonding was carried out in three primary teeth in case the teeth remained impacted and orthodontic traction was deemed necessary although spontaneous re-eruption of all five teeth occurred within a few months after surgery.

Numerous theories of tooth eruption have been proposed, most of which involve almost all of the tissues in or near an erupting tooth. However, none of these theories alone can account for complete tooth movement. At present, root elongation, alveolar bone remodeling, and periodontal ligament formation provide the most convincing model of tooth eruption ${ }^{13)}$. Root formation of the impacted teeth was complete in all five cases. It is diffi- cult to propose a clear explanation with respect to how the five primary teeth reported in this study, with fullygrown roots, spontaneously erupted after removal of the odontomas. Indeed, very little literature regarding spontaneous eruption of impacted primary teeth associated with odontomas is available. Otsuka et al. ${ }^{20)}$ observed that 8 of 9 primary teeth re-erupted after surgery, while Teruhisa et al. ${ }^{21)}$ and Yeung et al. ${ }^{22)}$ claimed that the chance of spontaneous eruption is slim in all cases. However, if we compare the prognoses of impacted permanent and primary teeth, primary teeth have a higher chance of spontaneous eruption than permanent teeth, which leads to a more positive prognosis ${ }^{20}$. A simple but convincing explanation for this observation is that the depth of impaction is shallower in primary teeth because of the presence of a physical barrier, namely, the succedaneous tooth germ. Moreover, the alveolar bone that surrounds permanent teeth is denser than the one covering the primary tooth ${ }^{13)}$. Thus, when an obstacle that is obstructing the eruption pathway is removed, the impacted tooth can begin to move in the less pressurized gingival direction.

Based on this study, we formulated a policy for the treatment of impacted primary teeth. When impacted primary teeth have sufficient space to erupt in the dental arch, surgical exposure with removal of the overlying gingiva or any overlying odontoma should be performed and the impacted teeth kept under observation for three months. Orthodontic traction should be applied when the tooth fails to erupt. It is important to note that, in the cases described here, impaction of the primary teeth may be associated with disturbance in their permanent successors, and thus long-term observation is necessary through eruption of the permanent successors.

\section{Summary}

Impaction of primary teeth is a rare condition that is most often associated with the presence of supernumer- 
ary teeth or odontomas. All five cases presented in this report involved impaction of primary teeth caused by odontomas. Signs of spontaneous eruption of all primary teeth were observed within 3 months of odontoma removal. Although orthodontic traction is another useful treatment option for impacted teeth, one can expect the eruption of a primary tooth with a fully developed root only after surgically removing the odontoma.

\section{References}

1. Neville BW, Damm DD, Allen CM, et al. : Oral and Maxillofacial Pathology 2nd edn. Saunders, Missouri, USA, 631-632, 2002.

2. Sheehy EC, Odell EW, Al-Jaddir G : Odontomas in the primary dentition. J Dent Child, 71:73-76, 2004.

3. Hisatomi M, Asaumi J-I, Konouchi H, et al. : A case of complex odontoma associated with an impacted lower deciduous second molar and analysis of the 107 odontomas. Oral Dis, 8:100-105, 2002.

4. Kramar IRH, Pindborg JJ, Shear M : World Health Organization International Histological Classification of Tumors - Histological Typing of Odontogenic Tumours, 2nd edn., Springer-Verlag, Berlin Heidelberg, Germany, 11-42, 1992.

5. Stajcic ZZ : Odontoma associated with a primary tooth. J Pedod, 12:415-420, 1988.

6. Owens BM, Schuman NJ, Mincer HH, et al. : Dental odontomas: a retrospective study of 104 cas $^{-}$ es. J Clin Pediatr Dent, 21:261-264, 1997.

7. Katz RW : An analysis of compound and complex odontomas. J Dent Child, 56:445-449, 1989.

8. Regezi JA, Kerr DA, Courtney R : Odontogenic tumors: analysis of 706 cases. J Oral Surg, 36:771778, 1978.

9. Sohma Y, Takagi R, Hoshina $H$, et al. : Clinicostatistical evaluation of odontogenic tumors; Report of 110 cases during the past 23 years. Japanese J Oral Maxillofac Surg, 47:109-112, 2001.

10. Kaugars GE, Miller ME, Abbey LM : Odontomas. Oral Surg Oral Med Oral Pathol, 67:172-176, 1989.

11. de Oliveira BH, Campos V, Marcal S : Compound odontoma-diagnosis and treatment: three case reports. Pediatr Dent, 23:151-157, 2001.

12. Noonan RG : A compound odontoma associated with a deciduous tooth. Oral Surg Oral Med Oral Pathol, 32:740-742, 1971.

13. Andreasen JO, Petersen JK, Laskin DM : Textbook and Color Atlas of Tooth Impactions. Mosby, Missouri, USA, 23-26, 1997.

14. Motokawa W, Braham RL, Morris ME, et al. : Surgical exposure and orthodontic alignment of an unerupted primary maxillary second molar impacted by an odontoma and a dentigerous cyst: a case report. Quintessence Int, 21:159-162, 1990.

15. Brunetto AR, Turley PK, Brunetto AP, et al. : Impaction of primary maxillary canine by an odontoma: surgical and orthodontic management. Pediatr Dent, 13:301-302, 1991.

16. Haishima K, Haishima H, Yamada Y, et al. : Compound odontomes associated with impacted maxillary primary central incisors: report of two cases. Int J Paediatr Dent, 4:251-256, 1994.

17. Kilpatrick NM, Hardman PJ, Welbury RR : Dilaceration of a primary tooth. Int J Paediatr Dent, 1:151-153, 1991.

18. Yassin OM : Delayed eruption of maxillary primary cuspid associated with compound odontoma. J Clin Pediatr Dent, 23:147-149, 1999.

19. Tandon S, Radhika M : Compound composite odontoma in primary dentition - a case report. J Indian Soc Pedod Prev Dent, 16:111-114, 1998.

20. Otsuka Y, Mitomi T, Tomizawa M, et al. : A review of clinical features in 13 cases in impacted primary teeth. Int J Paediatr Dent, 11:57-63, 2001.

21. Teruhisa U, Murakami J, Hisatomi M, et al. : A case of unerupted lower primary second molar associated with compound odontoma. Open Dent J, 3: 173-176, 2009.

22. Yeung KH, Cheung RC, Tsang MM: Compound odontoma associated with an unerupted and dilacerated maxillary primary central incisor in a young patient. Int J Paediatr Dent, 13:208-212, 2003.

23. Han YB, Kim SO, Lee JH, et al. : Orthodontic traction of the lower deciduous second molar impacted by an odontoma. J Korean Acad Pediatr Dent, 36: 84-88, 2009.

24. Ryu JR, Kim YJ, Kim HJ, et al. : Eruption disturbance associated with a developing odontoma. J Korean Acad Pediatr Dent, 37:505-511, 2010. 


\title{
국문초록
}

\section{치아종에 의한 유치의 매복: 증례 보고}

\author{
김정우 · 현홍근 · 김영재 · 김정욱 · 장기택 · 김종철 · 한세현 · 이상훈 \\ 서울대학교 치의학대학원 소아치과학교실
}

치아종은 유치나 영구치배의 지속적인 치배 형성이나 법랑기 세포들의 비정상적인 증식의 결과로 발생하는 방사선 불투과 성 병소로, 비교적 흔한 치원성 종양이며 인접한 치아의 맹출을 방해 할 수 있다. 치아종은 영구치열기에서 주로 관찰되고, 유치열기에서는 매우 드문 것으로 보고되고 있다.

본 증례 보고에서는 치아종에 의해 매복된 유치가 치아종의 외과적 발거 후 자연 맹출된 증례들을 보고하고자 한다. 매복 유치는 계승 영구치의 발육과 맹출 문제를 야기할 수 있기 때문에 치아종이 제거된 후에도 계승 영구치가 맹출할 때까지 장 기적인 검사 및 관찰이 필요하다.

주요어: 치아종, 유치의 매복, 자발적 맹출 